\title{
Analysis of Legal Issues
}

\section{Steven C. Combs}

Communication Studies,

Loyola Marymount University

7900 Loyola Boulevard, Los Angeles, CA 90045-8231

U.S.A

E-mail: scombs@lmu.edu

\section{Student Objectives:}

(1) To apply principles of critical thinking to a case study; (2) to set priorities and write efficiently in order to comply with page length limitations; (3) to use facts, evidence, definitions, and legal principles selectively in crafting arguments; and (4) to recognize how one's audience and goal affect the choice of reasoning standards and methods of expression.

\section{Exercise:}

(1) Students write one page of argumentation for each of the following roles: (A) You are the plaintiff attorney representing SCTI. Your goal is to convince the jury that your side is correct and to award you appropriate damages.

(B) You are the defense attorney representing Bernie Miller. Your goal is to convince the jury that your client is innocent and/or that any damages are insignificant.

(C) You are the foreperson of the jury. Your goal is to use the arguments provided in (A) and (B) to arrive at a just verdict.

(2) Students write one-two pages of analysis showing how the goal and audience affected the choice of reasoning and use of language in (A), (B), and (C). Consider how a judge might have evaluated the case differently from the jury foreperson. Use the definitions found in the Legal Dictionary and the Overview of Contract Law to present your case. Note that not all of the nformation contained in these materials is relevant. You must decide what is necessary for your analysis. You may be tempted to alter some of the information in the cases. Avoid this temptation! If you read (infer) between the lines, defend your interpretation. Do not, however, add any information that is not clearly implied within the case. Finally, assume that the jury is composed of representative members of your community. 


\section{Stipulated Facts:}

Bernie Miller, a Phoenix small business owner, responded to a post card solicitation and ordered a correspondence course in business accounting. He believed that if he had better knowledge of the principles of accounting he could apply them to his record keeping and thus save money by having to pay less to the government in taxes. The Institute guaranteed to evaluate the progress of each student by grading course work sent into the headquarters. The Institute also had instructors available each evening through a toll-free number for those who needed more intensive assistance. The cost of the course was $\$ 499.00$. Printed just above the place on the card for his signature appeared the following words, "Upon acceptance of the course materials, the signatory of this card agrees to pay Southern California Trade Institute [SCTI] the full amount of the course with the return of the first lesson." Bernie signed the card and mailed it.

The following morning, Bernie experienced a great deal of buyer's remorse because he knew he didn't have the time to commit to the course. He called directory assistance, solicited the phone number for the school, and telephoned. He spoke to Constance Allen. He told her that he had sent the card the previous day and wanted them to disregard the order since he decided not to go through with the course. She told him she would do what she could to intercept the card. Three weeks later the materials arrived. Mrs. Miller signed for acceptance. When her husband returned home, he picked up the package, wrote refused on the address card, drove it to the post office, and mailed it to the Institute never having opened it.

A few weeks later, form letters arrived prodding Bernie to send in his money with his first lesson. Bernie ignored the letters, assuming that his returned materials had not been fully processed. After about two months, representatives from the Institute started calling demanding the money for the course. Bernie phoned a customer service representative and explained that he had spoken with Constance Allen, who told him she would take care of his cancellation, and had returned the materials because he felt they had been forwarded in error. They responded by telling him that they had the signature of a "Mary Miller-wife" on the acceptance card that was returned from the delivery. They also told him that there was nothing in the original offer that he signed when he ordered the materials that allowed him to return the copyrighted materials without payment. Additionally, they had not received the returned materials and they believed that he still had them, and if he didn't pay within three days, legal actions would be filed against him. Nine weeks after he had responded to the post card solicitation, Bernie was served with a lawsuit for breach of contract. The suit claimed damages of $\$ 499.00$ for the cost of the course and an additional $\$ 300.00$ for court and collection costs. 


\section{Legal Dictionary:}

Acceptance, Absolute: An express and positive agreement to pay the bill according to its tenor.

Acceptanc, Conditional: An engagement to pay the bill on the happening of a condition.

Agent: A person authorized by another to act for him, one entrusted with another's business; one who represents and acts for another under the contract or relation of agency.

Apparent Agent: One whom the principal, either intentionally or by want of ordinary care, induces third persons to believe to be his agent, though he has not, either expressly or by implication, conferred authority on him. A person who, whether or not authorized, reasonably appears to a third person, because of manifestations of another, to be authorized to act as agent for such other.

Breach of Contract: Failure, without legal excuse or standing, to perform any promise that forms the whole or part of a contract.

Cancellation: Abandonment of contract.

Contract: A promissory agreement between two or more persons that creates, modifies, or destroys a legal relationship. An agreement, upon sufficient consideration, to do or not do a particular thing.

Fraud: The intentional perversion of truth, by words or conduct, for the purpose of inducing another in reliance upon it to part with some valuable thing belonging to him or her.

Notify: To give notice to; to inform by words or writing, in person or by message; to make known.

Offer: To present for acceptance or rejection; to exhibit something that may be taken or received or not. An offer must be so definite in its terms, or require such definite terms in acceptance, that the promise and the performance to be rendered to and by each part are reasonably certain. The word "offer" as used in a statute providing that the buyer, to rescind a sale, must offer within a reasonable time to return the goods, is synonymous with the word "tender."

Reasonable Notice: Such notice or information of a fact as may fairly and properly be expected or required in the particular circumstances.

Subscriber: One who writes his name under a written instrument; whether for the purpose of authenticating or attesting it, of adopting its terms as his own expressions, or of binding himself by an engagement that it contains.

Substantial Performance: Exists where there has been no willful departure from the terms of the contract, and where the contract has been honestly and faithfully performed in its material and substantial particulars, and the only variance from the strict and literal performance consists of technical or unimportant omissions or defects. 
Tender: An offer of money; the act by which one produces and offers to a person holding a claim or demand against him the amount of money which he considers and admits to be due, in satisfaction of such claim or demand, without any stipulation or condition. The offer of performance, not performance itself, and, when unjustifiably refused, places other party in default and permits party making tender to exercise remedies for breach of contract.

\section{Overview of Contract Law:}

Contract law is based on a party's failure to fulfill an obligation that the parties voluntarily created for themselves. A contract is an agreement between two or more parties to do a certain thing in exchange for a promise from another person to do another thing. The agreement must be entered into freely and willingly by persons who are capable of understanding and consenting to the terms (Bronstein, 1990). Contracts that involve mentally challenged persons, minors, or individuals that have been coerced or misled about significant issues may be unenforceable.

A contract is created when one party makes an offer and the other party accepts the offer. Contracts differ from "promises" because a contract requires that both parties receive some benefit or "consideration" from the contract. The consideration cannot be something or some act that is illegal or immoral.

The failure of one party to uphold a valid agreement is considered a "breach of contract." Breach of contract allows a party to bring the party in default to court and to get the court to correct the situation. In order to prove a breach of contract one must establish the terms of the contract, show a failure to adhere to the terms, and demonstrate that the failure resulted in a harm to the plaintiff (Bronstein, 1990).

\section{Reference}

Bronstein, D. A. (1990). Demystifying the law: An introduction for professionals. Chelsea, MI: Lewis Publishers.

\section{Materials}

Legal Analysis Exercise; The Southern California Trade Institute (SCTI) v. Bernard Miller; Legal Dictionary; Overview of Contract Law. 